\title{
Honeybee health in South America
}

\author{
Matías Maggi ${ }^{1}$, Karina Antúnez ${ }^{2}$, Ciro Invernizzi ${ }^{3}$, Patricia AldeA ${ }^{4}$, Marisol Vargas ${ }^{5}$, \\ Pedro Negri ${ }^{1}$, Constanza Brasesco ${ }^{1}$, David De $\mathrm{JONG}^{6}$, Dejair Message ${ }^{7}$, \\ Erica Weinstein TeIXeIRA ${ }^{8}$, Judith PrinciPal ${ }^{9}$, Carlos Barrios $^{9}$, Sergio Ruffinengo ${ }^{10}$, \\ Rafael Rodríguez Da SiLva ${ }^{4}$, Martín Eguaras ${ }^{1,11}$

\footnotetext{
${ }^{1}$ Centro de Investigación de abejas sociales (CIAs), Facultad de Ciencias Exactas y Naturales, Universidad Nacional de Mar del Plata (UNMdP, CP 7600), CONICET, Mar del Plata, Argentina

${ }^{2}$ Instituto de Investigaciones Biológicas Clemente Estable, Avenida Italia 3318, CP 11600, Montevideo, Uruguay ${ }^{3}$ Facultad de Ciencias, Iguá 4225, CP 11400, Montevideo, Uruguay

${ }^{4}$ Centro de Emprendimiento Apícola, Facultad Silvoagropecuaria de la Universidad Mayor, CEAPIMAYOR-Camino La Pirámide 5750 Huechuraba, Santiago, Chile 8580745

${ }^{5}$ Laboratorio de Virología, Universidad de Concepción, Avenida Vicente Méndez 595, Chillán, Chile 3780000

${ }^{6}$ Depto. de Genética, Faculdade de Medicina, Universidade de São Paulo, Ribeirão Preto, SP, Brazil

${ }^{7}$ Depto. de Ciencias Animais, Universidade Federal do Semiárido, Mossoro, RN, Brazil

${ }^{8}$ Laboratorio de Sanidade Apicola, Polo Regional do Vale do Paraiba, Agencia Paulista de Tecnologia dos Agronegocios, Secretaria de Agricultura e Abastecimento do Estado de São Paulo, Pindamonhangaba, SP, Brazil

"Universidad Centroccidental "Lisandro Alvarado" (UCLA), Decanato de Ciencias Veterinarias, Estación de Apicultura,

Núcleo Héctor Ochoa Zuleta, Redoma vía Agua viva, Tarabana, Municipio Palavecino, Estado Lara, Venezuela

${ }^{10}$ Facultad de Ciencias Agrarias, Universidad Nacional de Mar del Plata, Balcarce, Argentina

${ }^{11}$ Laboratorio de Artrópodos, Centro de Investigación de abejas sociales (CIAS), Facultad de Ciencias Exactas y Naturales, Universidad Nacional de Mar del Plata (UNMdP, CP 7600), Mar del Plata, Argentina
}

Received 22 August 2015 - Revised 7 March 2016 - Accepted 31 March 2016

\begin{abstract}
Honeybees are essential components to modern agriculture and economy. However, a continuous increase in cases of colony losses and colony depopulation are being reported worldwide. This critical situation has put the fragile equilibrium between bees and plants on the edge. As a consequence, several scientists have begun to focus their lines of research on this issue. Most researchers agree that there is no single explanation for the observed colony losses. Instead, these losses result from a synergistic interaction between different stressors. South America is not the exception; several cases of colony losses and colony depopulation were reported by beekeepers throughout the continent, yet no accurate data has been published to date. Therefore, this article attempts to analyze the past and present situation of honeybee health in South America, specifically in Argentina, Chile, Uruguay, Brazil, and Venezuela. Furthermore, it is intended to serve as a comparison to future colony losses, as well as to provide guidance for future hypothesis-driven research on the causes of colony mortality. We evaluate the impact of the main parasites and pathogens affecting honeybee colonies and discuss the role of each with respect to reported honeybee losses. We also contemplate the main challenges that each nation must confront with regards to honeybee health.
\end{abstract}

\section{Apis mellifera / health / colony losses / South America}

\section{INTRODUCTION}

Along with wild bees, honeybees are the most important crop pollinators (Buchmann and

Corresponding author: M. Eguaras, mjeguaras@gmail.com Nabhan 1996; Kremen et al 2002; Klein et al Manuscript Editor: Yves Le Conte 2012). Apis mellifera pollinates $77 \%$ of the plants responsible for producing food resources which 
sustain the global human population (Buchmann and Nabhan 1996). Since 1998, individual beekeepers have reported the unusual weakening and mortality of colonies, particularly in France, Belgium, Switzerland, Germany, the United Kingdom, the Netherlands, Italy, Spain, and North America (Le Conte et al. 2010; Neumann and Carreck 2010). Most scientists agree that there is no single explanation for the extensive colony losses, but that interactions between different stressors are likely involved (Potts et al 2010).

Taking into account that the only global data about bee losses available for South America (SA) (Latin America = LA) is the study published by Vandame and Palacio (2010), the main objective of this review is to serve as an update and reference on honeybee health status in this region. This review provides a detailed account of the current situation in SA countries, where beekeeping is more relevant from the point of view of economic and ecological information. This information is crucial to raising awareness among official sectors on the critical circumstances of these countries. Moreover, it represents the first association of researchers from SA, whose ultimate goal was to create a document that would describe the current health situation and serve in future decision making to promote honeybee conservation. Data from Brazil, Argentina, Uruguay, Chile, and Venezuela were used for this review due to two main reasons: a) Most peer-reviewed published studies from SA were performed in these countries (we have also included unpublished data and personal communications from the authors of this review, as well as from government agency reports); and b) these countries are the main honey producers in SA. We have structured this review firstly focusing on the current main biological hazards affecting A. mellifera in SA (varroosis, RNA viruses, nosemosis, American and European fouldbrood, and acarapisosis); and secondly focusing on other non-biological stressors impacting bee colonies in SA (river disease, agricultural intensification, pesticides, and Brazilian sacbrood disease). In addition, this review also presents the dissemination of each parasite in each country and the control measures used to manage these parasites. The impact of honeybee parasites (and pathogens) against native bees from SA is also discussed. This information for native bees was added due to the fact that they represent a source of new biological hazards for honey bees (and vice versa as well) if both bee species superpose geographical distributions.

As stated by Vandame and Palacio (2010), for the case of Latin America (LA), evaluating bee health in SA is a difficult task. This is due to the fact that the SA region is large and highly diverse, with a wide range of climates (from tropical to temperate) and altitudes (from sea level to around $2000 \mathrm{~m}$ of altitude), with various types of beekeepers (who own from 15 to 15,000 colonies, running them as a business or as hobbyists), and there is limited published information on honeybee health in SA countries. The only published data on colony losses in SA were reported in Uruguay and Argentina (Invernizzi et al. 2011; Maggi et al. 2013). However, the main problem impeding the organization of the causes for colony losses has been the lack of connection networks between public and private institutions at the national and international levels. These would serve as a tool in order to exchange experiences, projects, and generate scientific publications regarding situations that involve each other, and would also make health, production, traceability, nutritional history, and other information available in order to seek ways to resolve these gaps. Moreover, conducting this review has shown the need to generate networking and collaborative working bodies in order to learn more about the reality of beekeeping in the countries included in this review and the rest of South America. For these reasons, estimating the exact number of hives and colony losses is a complex issue (Table I). Additionally, the current distribution of Africanized genes, which reveals better sanitary conditions, is inaccurate in SA. In Venezuela and Brazil, beekeepers utilize Africanized honeybees (De Jong 1984; Thimann 2001), while in Uruguay, most honeybees are hybrids between European bees and Africanized bees from Brazil (Collet et al. 2006). The persistence of the non-African haplotypes in western provinces may be due to a strong introduction of European queens (Branchiccela et al. 2014). Regarding Argentina and Chile, most of their bee populations belong to 
European lineages (Eguaras and Ruffinengo 2006; Delaplane 2014); however, Africanized individuals have also been detected in Argentina (Abrahamovich et al. 2007). Ecotypes of Africanized bees are more tolerant against attacks by parasites and pathogens, thus leading to different survival responses by honeybee populations against biotic threats such as Varroa destructor or Paenibacillus larvae. Nonetheless, many beekeepers are unaware of the ecotypes of bees that they have in their apiaries.

\section{THE MAIN BIOLOGICAL HAZARDS FOR HONEY BEES IN SA}

\subsection{Varroosis}

Varroa destructor is the main biological hazard for honeybees in temperate climates (Eguaras and Ruffinengo 2006). Countries like Argentina, Chile, and Uruguay suffer from the devastating effects of Varroa, and its presence has been associated with colony losses (Antúnez et al. 2015; Maggi et al. 2013).

The first report of $V$. destructor in SA was in Argentina in 1976 (Montiel and Piola 1976). Two years later, it was detected in Uruguay (Invernizzi et al. 2011), and in 1982, it was reported in Brazil by De Jong et al. (1982). Due to its presence in Argentina, the introduction of Varroa in Brazil was through Paraguay (De Jong et al. 1982). The presence of Varroa mites in Venezuela and Chile is recent: it was detected in Venezuela in 1991 (Principal et al. 1991) and in Chile in 1992 (Casanova and Perruolo 1992). Current studies have demonstrated that the Korean haplotype is cosmopolite in SA (Strapazzon et al. 2009; Maggi et al. 2012), to the point that the Japanese haplotype is nearly absent in SA countries. The island of Fernando de Noronha (Brazil) is the exception, where Italian bees were introduced into colonies that had been transported from mainland Brazil in 1984 (De Jong and Soares 1997).

Since the 1990s, reproductive success and dissemination of $V$. destructor have increased considerably (Maggi et al. 2010). In Chile, Neira et al. (2007) determined a prevalence of $80 \%$ of $V$. destructor. Nowadays, the average prevalence 
of varroosis in Chile is close to $93 \%$, with an infestation level in adult bees between 5 and $9 \%$ (Aldea et al. 2013a, b). Between 1985 and 2005 in Uruguay, $77.4 \%$ of the analyzed samples were infested, with a mean percentage of infestation of $7.9 \%$ (Invernizzi et al. 2011). Today, it is known that the mite presents a high prevalence in autumn (75.7\%). In Argentina, high Varroa prevalences (74\%) were reported in a national survey performed by SENASA in 2007 (Maggi et al. 2013). Recent studies performed in the Santa Fe Province (Argentina) have reported that high mite infestation rates are associated with poor nutrition, old queens, and climate conditions (Giacobino et al. 2014).

When Varroa was initially introduced to SA, mite infestations were controlled with only one cure per year using mainly synthetic acaricides, or even without acaricide treatment (Eguaras and Ruffinengo 2006; Invernizzi et al. 2011). However, this situation changed in the late $1990 \mathrm{~s}$, when overwintering losses associated with the mite were detected in different regions of the continent (Eguaras and Ruffinengo 2006; Invernizzi et al. 2011; Maggi et al. 2013). Today, V. destructor appears to be less virulent in tropical and subtropical regions where Africanized bees are present than in temperate regions; this situation has been reported through studies published in Argentina, East Uruguay, Brazil, and Venezuela (Casanova 2000; Moretto 2002; Vandame and Palacio 2010; Invernizzi et al. 2011).

The natural resistance of Africanized honeybees (AHB) to Varroa mites has been well documented in Venezuela and Brazil (Casanova 2000; Moretto 2002; Junkes et al. 2007). The hygienic and grooming behaviors of these bees have been considered a key factor in disease resistance (Corrêa-Marques et al. 2000; Invernizzi et al 2016). Likewise, Principal et al. (2004) and Piccirillo and Gonzalez (1995) have reported that infestation rates were low in AHB colonies, allowing beekeeping without the need of treatments for varroosis. Currently, Varroa infestation in Venezuela is not considered a serious problem (Principal, pers. commun.). Nevertheless, this scenario has been gradually changing in southern Brazil, where the percentage of fertile mites increased from $56 \%$ in the 1980 s to $86 \%$ in $2005-$
2006 (Carneiro et al. 2007). Infestation levels are higher in cool regions of Brazil as well as in first generation European/Africanized crosses (Moretto et al. 1991). Santos et al. (2014) has reported high Varroa prevalence for the São Paulo State in Brazil (95.7\%), with an overall average infestation of mites in adult bees of $5.41 \%$. Some beekeepers have attempted to use chemical controls against $V$. destructor instead of following recommendations of selecting for resistance. However, in the same regions where beekeepers allege that treatment for Varroa is necessary, others maintain highly productive colonies without any control. Some of these beekeepers use selection, especially for hygienic behavior, without resorting to chemical treatment (Message et al. 2012). Table II summarizes the surveys of $V$. destructor prevalence from different SA countries.

The widespread use of synthetic acaricides throughout the years in SA has generated a strong selective pressure on mite populations. In this context, mite populations that are resistant to amitraz, flumethrine, and coumaphos have emerged in SA (Maggi et al. 2009, 2011; Aldea and Rodríguez 2014). On the other hand, a decreased efficacy of fluvalinate has been detected in Uruguay and Argentina in zones where it has been used for many years (Fernández and García 1997; Invernizzi et al. 2011). To date, no cases of cross-resistance between acaricides or multiple resistances have been detected in SA.

In addition to resistance phenomena and control failures, the beekeeping industry in SA is suffering a dramatic negative effect in relation to wax adulteration and contamination, which affects colony survival (Medici et al. 2011). The presence of acaricides in beeswax also affects the population dynamics of $V$. destructor (Medici et al. 2015). There is only enough evidence in Argentina to correct sanitary plans: the study performed by Castro et al. (2010) demonstrated that comb foundation with high content of paraffin $(40 \%)$ presented more viability of bee brood than comb foundation without paraffin. Later, Medici et al. (2012) found that recycled beeswax without added paraffin wax $(0 \%)$ had high levels of coumaphos and fluvalinate contamination, and when paraffin wax was added in 


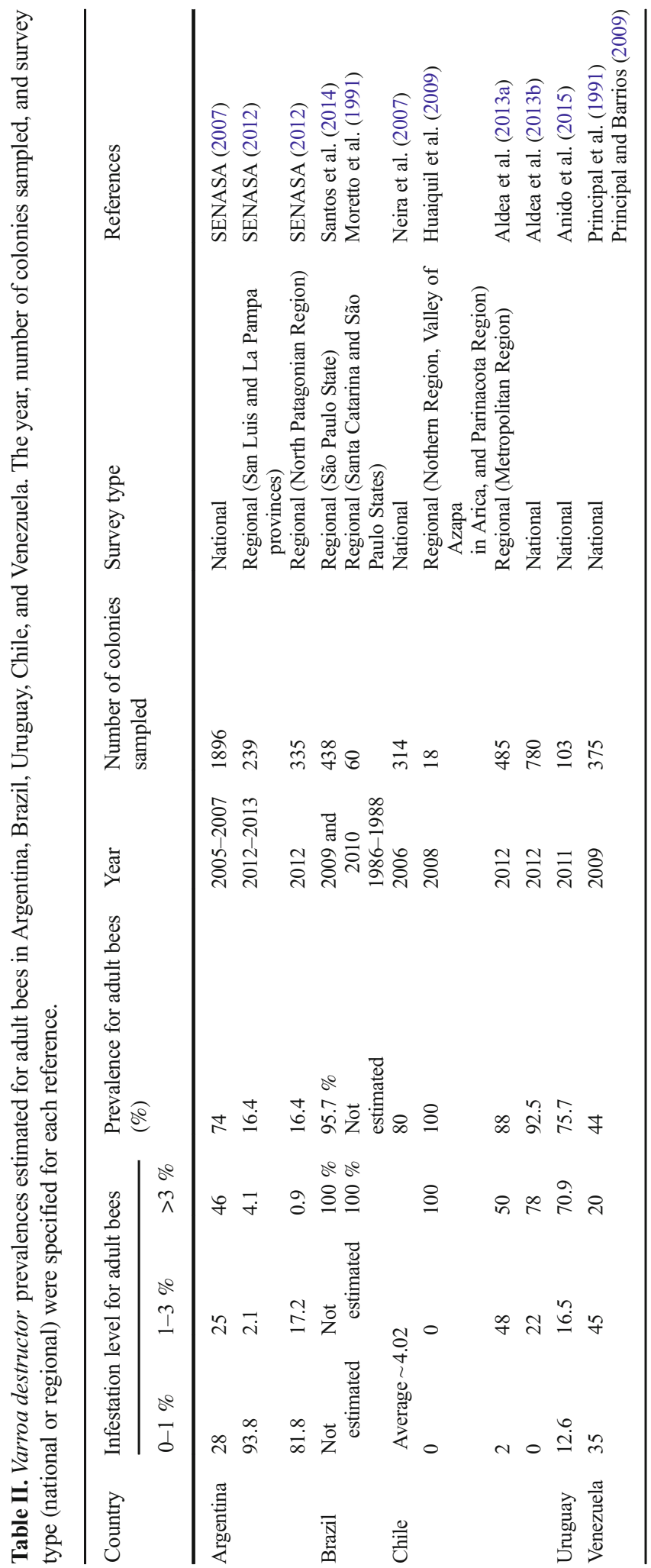


different percentages $(20 \%, 40 \%)$, the concentration of these components was lower. When the pesticide concentration decreased, an improvement in the bee survival rate was found. In this way, larvae developed in beeswax foundation without paraffin wax, exposed at higher concentration of pollutant residues, were more vulnerable to the toxic effects of the acaricides. Furthermore, a recent study performed in Argentina by Medici et al. (2015) documented a positive correlation between the resistance index of coumaphos in $V$. destructor and the levels of the organophosphate found in beeswax. These studies and the reports of phenomena of resistance to acaricides in Argentina (Maggi et al. 2008, 2009, 2010) provided enough evidence to correct sanitary plans after being reported to public health agencies and beekeepers in order to modify the use and rotation of acaricides. Uruguay and Chile still require more in-depth studies related to this topic; the fact that the presence of acaricides in beeswax affects the susceptibility of $V$. destructor (Medici et al. 2015) is extremely worrying. The development of new acaricides from plants (propolis, essential oils, organic acids) is a key factor to revert this situation. In this sense, some recent studies report promising molecules for Varroa control (Damiani et al. 2010, 2014; Maggi et al. 2015 among others).

\subsection{RNA viruses}

The first reports on RNA viruses in SA were carried out by Message et al. (1996), with honeybees from Brazil and Argentina. Using the immunodiffusion technique, these authors reported the presence of the Filamentous Virus (FV), Acute Bee Paralysis Virus (ABPV), Black Queen Cell Virus (BQCV), and Cloudy Wing Virus (CWV) in Brazilian honey bees, and the Sacbrood bee virus (SBV) in Argentine samples. On the other hand, Marcangeli et al. (1992) reported the presence of bees with deformed wings emerging from cells not parasitized by $V$. destructor in Argentina, a symptom associated today with the presence of Deformed Wing Virus (DWV) (Lanzi et al. 2006).

Through the use of molecular methods, Antúnez et al. (2006) reported the presence of ABPV, BQCV, Chronic bee paralysis virus
(CBPV), DWV, and Sacbrood virus (SBV) in Uruguay. Later, these same viruses were detected in Brazil with the exception of CBPV (Teixeira et al. 2008; Freiberg et al. 2012), and in Argentina (Reynaldi et al. 2010; Brasesco et al. 2013), and in Chile, with the exception of CBPV (Barriga et al. 2012; Rodríguez et al. 2012, 2014). RNA viruses were detected in colonies from apiaries with antecedents of colony losses and in apiaries without clinical symptoms of diseases as well. In Peru, only DWV and BQCV were found, although the study included a limited number of colonies (Yañez et al. 2014).

In the case of Israeli Acute Paralysis Virus (IAPV), this virus has only been detected in Argentina and Brazil (Reynaldi et al. 2011; Teixeira et al. 2012). It has not been detected in Uruguay, although extensive analyses have been performed (Anido et al. 2015; Antúnez et al. 2015). Regarding $\mathrm{KBV}$, there are no records about its presence in SA (Anido et al. 2015; Teixeira et al. 2008). Table III summarizes all viral diseases reported in SA.

It is quite difficult to estimate the prevalence of viruses in SA, since most studies were carried out in apiaries with colony losses (Antúnez et al 2006; Teixeira et al. 2008; Reynaldi et al. 2010; Rodríguez et al. 2012) and the obtained prevalences may be overestimated. Taking only into consideration studies with random sampling around the country (Argentina and Uruguay), prevalence was between 1 and $14.6 \%$ for ABPV, 2 and $87.4 \%$ for BQCV, 1 and $25 \%$ for CBPV, 3 and $47 \%$ for DWV, and 2 and $26 \%$ for SBV (Anido et al. 2015; Castilla et al. 2015). These viruses have been detected all year round, although higher prevalence and viral loads were detected during autumn, coinciding with $V$. destructor infestation (Antúnez et al. 2015). In fact, $V$. destructor infestation level has been associated with DWV viral load, and colonies with infestation above $4 \%$ presented a six times greater risk of being infected with DWV (Anido et al. 2015).

Besides the presence of RNA viruses in A. mellifera, these viruses also infect native honey bees in SA. BQCV, DWV, and SBV have been detected in the bumblebee Bombus atratus in Argentina (Reynaldi et al 2013), while these 


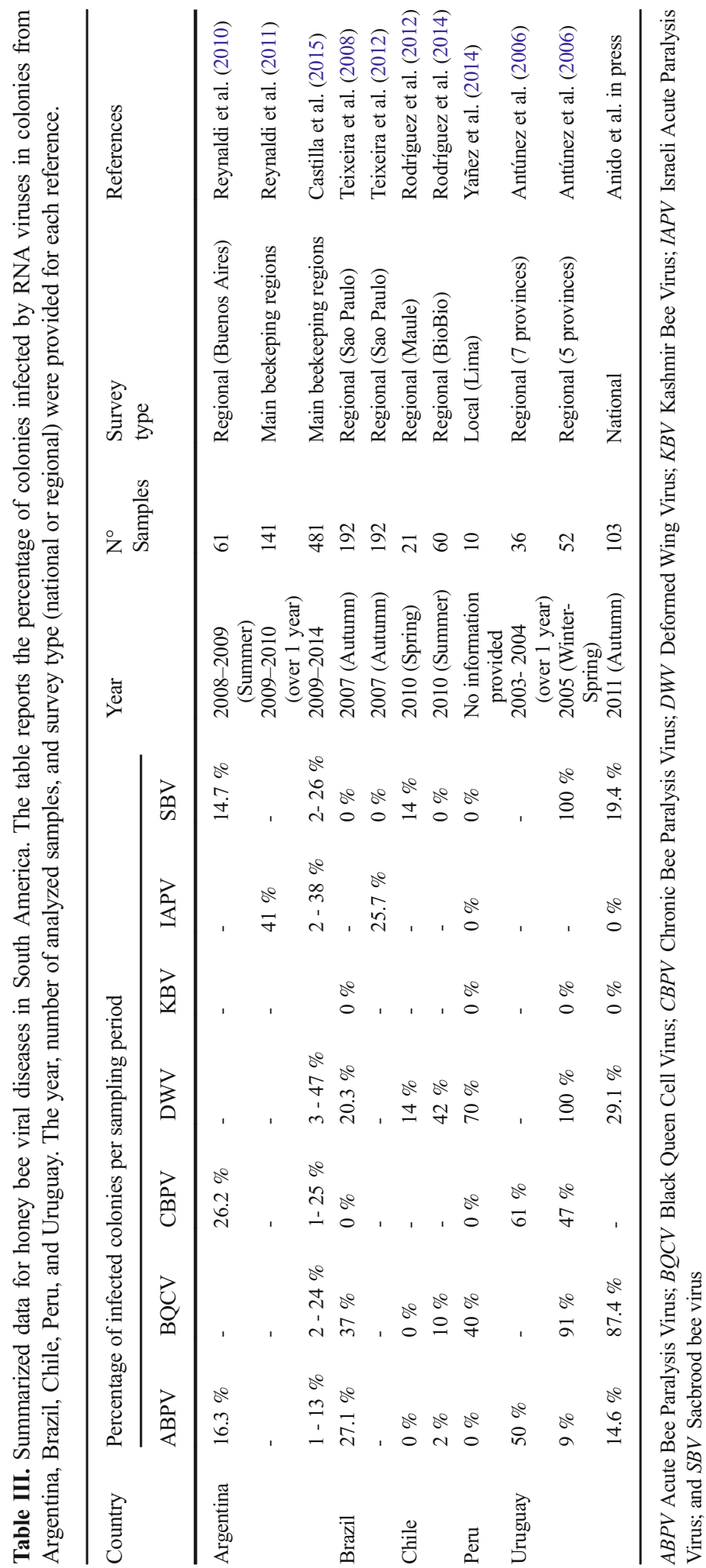




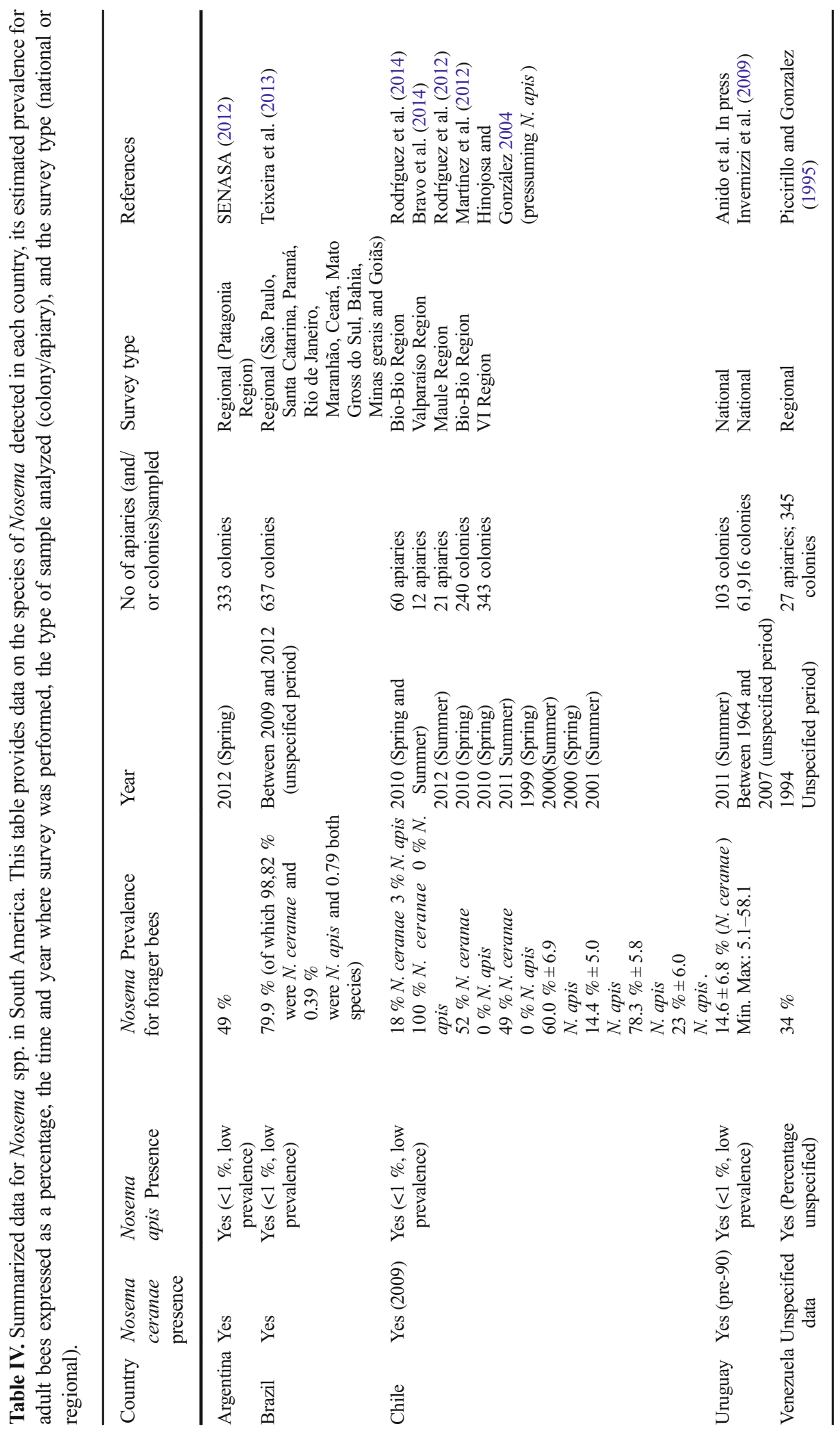


viruses, along with ABPV and Like Sinai Virus (LSV), were detected in B. atratus in Colombia (Gamboa et al. 2015). DWV has also been detected in the carpenter bee Xylocopa augusti (Lucia et al. 2014).

Considering all of these studies, it is suggested that ABPV, BQCV, DWV, and SBV are widely spread in SA.

\subsection{Nosemosis}

The microsporidian Nosema apis has been present in SA for at least 90 years. The first documented detection of N. apis was in Brazil in 1928 in apiaries near Porto Alegre in the Rio Grande do Sul state (Message et al. 2012). In Uruguay, it has been recognized since 1940 (Invernizzi et al 2011), in Argentina since the mid-1950s (Cornejo et al. 1970), and in Chile since 1978 (Bravo et al. 2014). For these countries, during those years it was assumed that only $N$. apis was present and infecting honeybee colonies. Although nosemosis affects bee production, the effects of this parasite on honeybee colonies were never reported as "lethal" (Cornejo et al. 1970).

Nowadays, the current situation for nosemosis in SA is very different from the situation in the past. Several epidemiological surveys of Nosema spp. were performed, and in most of them, only $N$. ceranae was detected (Table IV). This new Nosema species appears to have been active in Brazil since 1979 (Teixeira et al. 2013). Invernizzi et al. (2009) also reported that this parasite has been present in Uruguay since 1990. The first detection of $N$. ceranae in Chile was in 2009, from samples analyzed by the National Sanitary Service (SAG 2010). In Argentina, its detection was reported in 2011 (Medici et al. 2012). Currently, $N$. apis is still encountered in some regions of SA, but it has a very low prevalence (Anido et al. 2015; Medici et al. 2012; Aldea et al. 2013b; Rodríguez et al. 2014) (Table IV).

The impact of Nosema on honeybee colonies is variable. In regions in which Africanized bees are present, no damage is reported. What is more, different levels of resistance to $N$. ceranae have been reported among Africanized bees, and this resistance has been associated with vitellogenin levels (Mendoza et al. 2014). In the 1990s in
Brazil, Nosema spores were found in adult bee samples taken by beekeepers concerned about losses, which was unexpected. In 2006, in about 1100 colonies that had been sampled from 20 apiaries in the São Paulo state, all had Nosema spores, though spore counts varied greatly, from 70,000 to 8 million spores per bee, also varying widely throughout the year (Teixeira et al. 2013). No clear evidence of correlation of such counts with colony decline was found in these apiaries or in other research carried out in Brazil (De Jong pers. commun.). Subsequently, the causative agent was identified as N. ceranae (Klee et al. 2007).

In Uruguay, nosemosis is not a great problem in most of the country. However, colonies were heavily infected with $N$. ceranae when they were moved to commercial plantations of Eucalyptus grandis (Mendoza et al. 2013). Despite this, beekeepers do not lose colonies if they are removed at the end of the flowering period, and these colonies frequently survived in good condition until the following spring (Mendoza et al. 2013). These trees, of great nectar and pollen potential, bloom between February and May, allowing the colonies to produce up to $50 \mathrm{~kg}$ of honey if environmental conditions are good. However, if the hives are not removed at the end of flowering, high losses often occur. Strong N. ceranae infection combined with a low pollen collection of poor botanical diversity (almost solely of E. grandis ) makes this environment suitable for studying the relationship between protein diet quality and nosemosis (Invernizzi et al. 2011).

Genetic origin of bees is also an important factor, since under the conditions of E. grandis plantations, Africanized colonies presented a lower level of infection by $N$. ceranae, had a larger population size, and produced more honey than Italian colonies (Mendoza et al. 2014).

In Chile, since the first report of $N$. ceranae in 2009 , different prevalences have been observed in the country. For example, $49 \%$ of Nosema prevalence was reported in 2012 from the Bio-Bio Region, (Martínez et al. 2012). Later, $100 \%$ of the prevalence in samples from 12 apiaries in the Valparaíso Region without mixed infection with $N$. apis was reported (Bravo et al. 2014). However, Rodríguez et al. (2014) also detected a low prevalence of $N$. apis (3\%) in regions outside of 
Valparaiso. In this study, it was reported that hives located below $39^{\circ} 07^{\prime} 04.82$ 'S usually exhibit symptoms similar to those observed when $N$. apis is present (Rodríguez et al. 2014). In this part of the country, nosemosis is an important cause of winter bee losses in Chile (Aldea et al. 2013b).

Native bees are also infected by honeybee parasites. Plischuk et al. (2009) described the presence of $N$. ceranae in three species of Argentine native bumblebees. In Colombia, bumblebees were found to be infected by at least four different species of pathogens. In some cases, even up to eight species were found in a single specimen (Gamboa et al. 2015). N. ceranae was omnipresent. Recently in Uruguay, high prevalence and infection levels of $N$. ceranae were detected in Bombus atratus and Bombus bellicosus bumblebees (Arbulo et al. 2015).

\subsection{American Foulbrood}

American foulbrood (AFB) was first described in SA in Argentina, in 1989, constituting the first sanitary challenge for beekeepers to overcome. It was hypothesized that the entrance of Paenibacillus larvae, the causative agent, into the country was through bees imported from the USA (Alippi 1992). AFB quickly spread to most important beekeeping centers of the country (Alippi 1996), with incidences as high as $30 \%$ in some geographic areas (Marcangeli et al. 2005). It is believed that at least $30-45 \%$ of the colonies were lost due to AFB during those years (Eguaras, unpubl. data).

AFB disease spread to the neighboring country of Chile in 2002 and was controlled. Then, in 2005, new outbreaks were detected in different regions (SAG 2006). In order to evaluate the presence of $P$. larvae in honey as an indicator of colony health status (Antúnez et al. 2004), Morán (2011) analyzed approximately 1300 honey samples collected in the field fresh honey frames between 2004 and 2009. The results showed an estimated prevalence of $4 \%$ of P. larvae spores in the honey samples studied. Simultaneously, the bacterium spread to Uruguay, probably through the entrance of live material from Argentina (Piccini and Zunino 2001; Antúnez et al. 2007).
AFB quickly spread throughout the country, reaching a prevalence of $51 \%$ in honey collected in the field, from 2001-2002 (Antúnez et al. 2004). Nowadays, AFB is not a major problem, and the prevalence was estimated to be $2 \%$ in 2011 (Antúnez et al. 2012).

Regarding Brazil, the first report of AFB was in 2001, when spores of this bacterium were found in honey and bees collected from apiaries in Rio Grande do Sul, close to Uruguay (Schuch et al. 2003). Though the colonies had no AFB symptoms, they were all destroyed by burning. Subsequent analyses of honey samples collected in this state in 2005 were all negative, demonstrating that the disease had not propagated (Message et al. 2012). A second outbreak was detected in the Parana state in 2006; these colonies were destroyed and no further AFB cases were detected (Sattler 2008). It is speculated that the Africanized honey bees in Brazil have some degree of resistance to AFB, probably due to a high degree of hygienic behavior (Morais 2009) or due to the large amount of propolis used in their colonies (Bastos et al. 2008).

Finally, in Venezuela, AFB has yet to be reported (Principal, unpubl. data). Prevention and control measures of AFB in SA countries generally include vigilance for early diagnosis, isolation of apiaries with cases of AFB, and multiplication of healthy colonies with hygienic queens, among others (SENASA 2005; SAG 2007; MAG 2008; Harriet et al. 2013). Brazilian, Chilean, and Uruguayan authorities specifically recommend the burning of colonies containing clinical signs of the disease in order to control the outbreaks (SAG 2007; MAG 2008; Harriet et al. 2013). The use of antibiotics is not allowed, except in Argentina (SENASA 2005). The extensive use of tetracycline hydrochloride in this country has led to the development of resistant P. larvae isolates (Alippi 1996), which is an important concern for Argentine beekeepers. In contrast, in Uruguay and Chile, where its use is not authorized, resistant strains have not been detected (Piccini and Zunino 2001; Aldea et al. 2013b). In Uruguay, the use of ethanolic extract of propolis on colonies has been a useful prevention strategy (Antúnez et al. 2008). Currently, alternative strategies for the prevention and treatment of AFB are being studied, mainly based on essential oils (Fuselli et al. 2010; Sabate et al. 2012; Santos 
et al. 2012; Damiani et al. 2014; González et al. 2015; Piana et al. 2015), probiotics (Audisio et al. 2011), and propolis (Bastos et al. 2008).

\subsection{European Foulbrood}

European Foulbrood (EFB) was first reported in South America in 1954 (Message et al. 2012), then in 2009, it was reported in Argentina, Chile, and Uruguay to the OIE office (OIE 2014). In the present, the situation of this disease is unclear because it is typically managed by beekeepers without the sanitary agency in each country noticing. The use of antibiotics is not allowed, and strategies to reduce the prevalence are the same as in the case of AFB. In this sense, EFB is considered endemic and active in Argentina without data about the prevalence. The last report in Chile was in 2012, and in that year, the prevalence was less than $3 \%$ (SAG 2015). In Uruguay, the last official report was in May 2011, with unknown prevalence data in the country. Nonetheless, nowadays it does not represent an important threat for beekeeping (Invernizzi et al. 2011). This disease is now considered to be inactive in Venezuela, as it has been occasionally observed without generating negative consequences for the colonies (Principal, unpubl. data). Finally, even when it was considered to be present in Brazil, there was no official report or published data since it became relatively rare and sporadic after the colonies became Africanized in the 1960s and 1970s (De Jong Pers comm.). In recent years, symptoms similar to EFB disease have been found in colonies, especially in the South and Southeast of Brazil, although Melissococcus plutonius (causative agent of European Fouldbrood) was not present (Message, unpubl. data).

\subsection{Acarapisosis}

The tracheal mite Acarapis woodi was first reported in Argentina in 1944 (Lozano et al. 1987), in Venezuela in 1957, and later in Chile in 1962. In general, the situation concerning this mite on the continent is not clear. Eguaras et al. (1998) published the first scientific study about the dynamics of this mite across the different seasons in Argentina using only ten colonies. The determined prevalence was less than $4.26 \%$ in July (winter) and $0.4 \%$ in
November (spring) in 1994. This disease is not considered relevant in Argentina and the last official report in the country was in 2004 (OIE 2014). Currently, Szawarski et al. (2013) showed no positive samples in a national study carried out in 2014. Flechtmann (1977) published the first report of acarapisosis in Brazil, but nowadays there is no official or scientific data. In 2007, the presence of the tracheal mite was surveyed in Chile by Neira et al. (2007). This study reported that the mite was highly distributed in Chile. However, as a result from the sanitary vigilance from the National Sanitary Service (SAG), an average prevalence of $8 \%$ was determined in 2010 in the country (SAG 2015). In a more recent analysis with a major sample size, some areas with more than a $20 \%$ prevalence were found (especially in the case of unprofessional beekeepers), while other areas obtained negative values (Aldea et al. 2013b; Rodríguez et al. 2014). The relevance of the tracheal mite in Chile is unclear, as well as if the interaction between $V$. destructor and A. woodi is responsible, at least in part, for the high number of mortalities caused by Varroa (Aldea et al. 2013b). The last official report of tracheal mites in Uruguay was in 1997 to the OIE, but it did not represent a relevant problem for beekeepers. In 2012, the presence of $A$. woodi in the country was evaluated through microscopic analysis, but the pathogen was not detected, suggesting a low prevalence. Using molecular methods, the prevalence was estimated to be approximately $1-2.7 \%$.

Finally, in Venezuela, Wilson et al. (1985) found mites in tracheal tubes in adult workers of honeybees, confirming their presence in the country. Furthermore, Casanova and Perruolo (1992) found a $2.7 \%$ prevalence in apiaries in the Tachira State. To date, the infestation rate of Acarapis in Venezuela remains unknown.

\section{OTHER STRESSORS AFFECTING COLONY HEALTH IN SA}

\subsection{Agricultural intensification and use of pesticides}

In man-made landscapes, agricultural activities are the most frequent cause of species loss and extinction (Rosenzweig 1975). Vandame and 
Palacio (2010) stated that intensive crops are less abundant in LA than Europe or the US. As a consequence, a low impact of pesticides on bee population is observed in LA countries. The authors also reported that croplands represent a much higher proportion of the total land area in industrialized countries in comparison to LA (as a whole). Nevertheless, commercial agriculture has grown to unprecedented levels in the past years in SA lands. This has led to a loss of biodiversity and habitat fragmentation (Pacheco 2012). This expansion is primarily related to the increasing amount of land used for soybean cultivation observed in recent years in Brazil and Argentina, with expansion into Paraguay, Bolivia, and Uruguay (Pacheco 2012). According to FAOSTAT, the Americas contribute $84.6 \%$ of global soybean production (FAOSTAT 2016), with Brazil and Argentina being the main soybean producers in SA. Moreover, Brazil is ranked as the secondmost soybean producing country, while Argentina is the third (FAOSTAT 2016). The continuous increase of soybean monocultures in SA indirectly affects colony survival in two main ways: a) By loss of local flora available, which provides diversity in nectar and pollen source, relevant for a successful immune response (Negri et al. 2015); and b) By the use of pesticides; sudden mortality of bees is usually associated with pesticide use (Malaspina et al. 2008). Pesticides have been blamed for honeybee losses in many regions of Brazil, especially in agriculture zones (Message et al. 2012), and also in Uruguay (Pareja et al. 2011). In the latter country, fipronil and imidacloprid have been detected in high doses in depopulated colonies. Although foliar application of fipronil was prohibited in 2009, intoxication is still a problem (Pareja et al. 2011). Additionally, pesticides can also affect native bee populations in SA. Several studies have documented the negative impact of insecticides on stingless bees in SA (Barbosa et al. 2015; Jacob et al. 2015; Lourenço et al. 2012).

Sublethal doses of pesticides induce negative effects on honeybees (Nguyen et al. 2009; Xavier et al. 2015). In Brazil, de Almeida Rossi et al. (2013) reported that sublethal doses of imidacloprid induced negative effects on malpighian tubules of Africanized bees. Moreover,
Brazilian researchers reported that thiamethoxam, also a neonicotinoid, was toxic for bee larva in lower doses which alter bee development (Tavares et al. 2015).

Glyphosate, one of the most common herbicides used in Argentina, negatively affected learning behavior in adult bees when they were exposed to this herbicide (Herbert et al. 2014). However, clearly documented cases are rare in SA due to difficulties in collecting samples and in identifying the specific chemicals that cause the losses.

\subsection{River disease in Uruguay}

In the case of Uruguayan beekeeping, there is a syndrome that beekeepers call "River disease." It is characterized by the mass death of young larvae (specifically 1 and 2 days old) from colonies located close to the catchment area of rivers, especially along the center and west coast of the country during the end of the spring or early summer (Mendoza et al. 2012a). Affected colonies, in just few days, have no brood and begin to decline. It can trigger colony loss if the problem continues over time. This syndrome appeared 50 years ago, but sporadic cases have been recently reported (Mendoza et al. 2012b). Although Vandame and Palacio (2010) mentioned in their work that this decline seems to be an effect of food shortage in spring (apparently increasing in recent years due to loss of natural vegetation), current studies bring new evidences to light about this phenomenon. It is now speculated that the cause of bee toxicity is a toxic substance present in pollen that forager bees carry to colonies, since it has been observed that when colonies are relocated, they begin to slowly recover. The recovery is rapid when reserves of pollen and nectar are removed from the colony (Invernizzi, unpubl. data).

\subsection{Brazilian sacbrood disease (toxic pollen)}

In recent years, one of the main problems affecting beekeepers in the Atlantic rainforest and Cerrado Regions of Brazil is "Brazilian Sacbrood Disease" (Carvalho and Message 2004). This disease causes severe losses, weakening, and the 
death of thousands of colonies, often eliminating entire apiaries. The larvae die in the last instar and are filled with a clear liquid, similar to symptoms of larvae affected by the sacbrood disease virus, leading to suspicion of a virus disease. However, no viruses are found in the diseased larvae. Brazilian Sacbrood disease was found to be caused by pollen collected from several tree species known as Barbatimão (Stryphnodendron spp.) trees (Carvalho and Message 2004). In the laboratory, the symptoms can be recreated by feeding pollen from Stryphnodendron spp. (Silva et al. 2009). Feeding with floral extracts from this tree significantly reduces adult bee lifespan (Cintra et al. 2003), which helps to explain why strong honeybee colonies decline and die within a month.

\section{ARE THERE CASES OF COLONY COLLAPSE DISORDER (CCD) IN SA?}

Only in Brazil, in the Region of Altinopolis, SP, Message et al. (2010) detected two cases of rapid loss of strong colonies in closely monitored commercial apiaries within an interval of 15 days in 2008 , with symptoms similar to what has been described as CCD in the USA. As stated by Ellis et al. (2010), in collapsed (dead) colonies, CCD may produce the following symptoms: 1) The complete absence of adult bees in colonies with few or no dead bees in / around colonies; 2) the presence of capped brood; and 3) the presence of food stores that are not robbed by other bees or typical colony pests. CCD symptoms often associated with collapsing (weakening) colonies may include: 1) An insufficient number of bees to maintain the amount of brood in the colony; 2) workforce composed largely of younger adult bees; 3 ) the queen is present; and 4) the cluster of bees is reluctant to consume food. The IAPV, APV, BQCV, and DWV viruses, as well as Spiroplasmaapis and Leptomonas apis (Teixeira et al. 2008), were detected in bees from the same region. All of the colonies that were analyzed were also infected with the microsporidian $N$. ceranae and were infested with the $V$. destructor mite.

A severe case of bee decline was also reported in the Santa Catarina state in 2011, where over 100,000 of 350,000 colonies died within a few months. In some regions, over $90 \%$ of the colonies were lost. These losses have been primarily attributed to bee viruses, interacting with the $V$. destructor mite, the microsporidian $N$. ceranae, and also to pesticides, including fipronil and neonicotinoids, which are widely used in Brazilian agriculture (Message et al. 2012).

\section{FINAL REMARKS AND CONCLUSIONS}

In the present manuscript, we present a review regarding the main hazards for A. mellifera in Argentina, Brazil, Uruguay, Chile, and Venezuela as an attempt to expand the information on honeybee health status in SA and to explain the high percentage of colony losses reported throughout this review. Given the decline of wild non-honey bee pollinators (Potts et al. 2010), data about A. mellifera health in SA lands becomes increasingly important for pollination service and honey production. Furthermore, by studying the current health status of European and Africanized bees in $\mathrm{SA}$, this provides a way to contribute to information about threats towards populations of native bees. The worldwide spread of diseases is considered a major threat to biodiversity and a possible driver of the decline in pollinator populations, particularly when novel species or strains of parasites emerge (Maharramov et al. 2013). Thus, reviewing the sanitary situation in SA contributes by avoiding the future apparition and/or spreading of emerging diseases in other bee species.

There is no doubt that the sanitary situation of beekeeping in SA is complex. Over 6 million beekeepers exist in SA (Table I), and a mean of $30 \%$ of colony losses (at least) are estimated per year, at least in temperate climates (Maggi et al. 2013; SENASA 2015; USAID-Brasil 2006; Vilela and Araujo 2006; DIGEGRA-MGAP 2014; Laval et al. 2010). Similar values of colony losses were reported in other parts of the world. For example, in the USA, vanEngelsdorp et al. $(2008,2010)$ reported colony losses for fall/winter 2006-2007 and 2007-2008 to be $31 \%$ and $36 \%$, respectively (vanEngelsdorp et al. 2008, 2010). In the fall of 2006, some beekeepers in the USA reported losing 30-90\% of their colonies (Ellis et al. 
2010). Recently, Lee et al. (2015) reported colony losses in the USA to be $19.8 \%$ during the summer, $23.7 \%$ during the winter, and $34.1 \%$ for the whole year. Average losses were $15.1 \%$ during the summer, $44.8 \%$ during the winter, and $51.1 \%$ for the whole year. While total winter loss was one of the lowest reported in 8 years, $66 \%$ of all beekeepers had higher losses than they deemed acceptable. In Canada, winter losses (34-36\%) were also reported from 2006 to 2009 (Currie et al. 2010). Europe also suffers colony losses each year (Le Conte et al. 2010; Van der Zee 2010, among others).

The cause(s) of colony losses in North America and Europe remains under investigation. In the USA, Israeli acute paralysis virus (IAPV) has been found in many samples taken from colonies exhibiting CCD-like symptoms, although this is not believed to be the sole cause of CCD (CoxFoster et al. 2007). According to Ellis et al. (2010), the primary hypotheses include: 1) traditional bee pests and pathogens; 2) how the CCD bees in the U.S. were managed (management stress); 3 ) queen source (poor genetic biodiversity); 4) chemical use in bee colonies to control bee pests / pathogens; 5) chemical toxins present in the environment; 6) $V$. destructor mites and associated pathogens; 7) bee nutritional fitness; 8) undiscovered / newly discovered pests and pathogens or increasing virulence of existing pathogens; and 9) potential synergistic interactions between two or more of the above hypotheses. In the case of Canada, increased rates of winter colony losses were most likely the result of regional differences in weather patterns that affected forage availability for bees, fall feeding management, mite and bee population growth, $V$. destructor treatment timing, the presence of Nosema spp., viruses and other diseases, and the spring build-up of colonies (Currie et al 2010). These stressors interacting in combination affected colony survival, but direct and indirect effects associated with acaricide resistance and the failure to control $V$. destructor mites are believed to be the most important factors related to colony loss in Canada (Currie et al 2010).

What are the main reasons for the high colony losses reported in SA? Are these the same factors that are active in other regions of the world? The answer is complex, but if anything is clear, it is that CCD phenomenon is not the only factor responsible for the bee colony losses reported in SA.

The following are the main causes of the losses observed in SA:

- Varroa mites seems to be the major threat to A. mellifera in SA, even in countries with AHB. This is explained by the direct and indirect damage produced to bees by the mites by feeding on bees and/or by the transmission of lethal RNA viruses, respectively.

- The intensive acaricide use registered in many countries for Varroa mite control. The abusive use of acaricides (coumaphos, amitraz, fluvalinate and flumethrin) generates resistant mite populations, wax contamination, and bee intoxication.

- Agriculture intensification. Although further studies are still needed, the major threats related to this topic for bees are: 1) loss of angiosperm diversity; 2) use of pesticides such as neonicotinoids and/or glyphosate among others; and 3) habitat fragmentation.

- Phenomena related to bee nutrition. River disease (in Uruguay), the Brazilian sacbrood disease (in Brazil), and nosemosis in temperate climates (Uruguay and Argentina) are other causes of eventual colony losses in SA that are extremely related to bee nutrition status.

- The presence of Africanized bees appears to be a crucial factor that affects the survival of honeybees. Beekeepers and researchers have found these bees to be more resistant to pathogens and parasites than European bees. Bees from Venezuela and Brazil (and some provinces in Uruguay and Argentina) are able to coexist with $V$. destructor. Perhaps the most complicated countries in terms of bee health are Argentina and Chile, due to the fact that most of their bee populations belong to European lineages, which are highly susceptible to attacks by parasites and pathogens.

The only way to preserve bee populations in SA is by understanding the bee biology and pest biology for each region. Bee populations with enhanced hygienic behavior (AHB) are more 
likely to survive in comparison to European bees in SA. In regions where bees present hygienic or grooming behavior, the use of pesticides should be applied, taking into account this "natural" bee defense against parasites. The expression of this complex bee/parasite/pathogen system is also affected by non-biotic stressors, such as climate conditions, land use, or bee nutrition. The yearly documentation of colony losses is critical in order to put losses into context and identify potential causes of mortality. Continuous monitoring of bee populations in SA is required, and this is impossible to avoid if colony losses are still observed and reported in the current global situation.

\section{ACKNOWLEDGMENTS}

The authors would like to acknowledge the valuable suggestions made by two anonymous reviewers. Their comments have improved this manuscript.

\section{La santé des abeilles en Amérique du Sud}

Apis mellifera / mortalité des colonies / surveillance sanitaire / continent sud-américain / parasite / pathogène

\section{Gesundheitszustand der Honigbienen in Südamerika}

\section{Apis mellifera / Gesundheit / Kolonierverluste / Südamerika}

\section{REFERENCES}

Abrahamovich, A., Atela, O., De la Rúa, P., Galián, J. (2007) Assessment of the mitochondrial origin of honey bees from Argentina. J. Apic. Res. Bee World 46(3), 191-194

Aldea P., Rodríguez R. (2014) Factors affecting sanitary control of Varroa destructor in Chile. The IV COLOSS Workshop on "Varroa control strategies" in Bled, Slovenia May 22- 23. Abstract book pp. 32

Aldea, P., Rodríguez, R., Olivares, A., Farfán, M., Riveros, D., Núñez, F., Trivelli, L. (2013a) Effect of ambient temperature and humidity conditions on the efficacy of organic treatments against Varroa destructor in different climatic zones of Chile. J. Agric. Sci. Technol. A 3, 474-483

Aldea P., Durán N., Del Río P., Reinike E., Rodríguez R. (2013b) Health status determination at the beginning of productive season in apiaries from Melipilla Province,
Metropolitan Region of Chile. In XXXXIII International Apicultural Congress between 29 September and 04 October Ukraine. Abstract book pp. 183

Alippi, A.M. (1992) Characterization of Bacillus larvae White, the causative agent of American foulbrood of honey-bees. First record of its occurrence in Argentina. Rev. Argent. Microbiol. 24, 67-72

Alippi, A.M. (1996) Characterization of isolates of Paenibacillus larvae with biochemical type and oxytetracycline resistance. Rev. Argent. Microbiol. 28, 197-203

Anido, M., Branchiccela, B., Castelli, L., Harriet, J., Campá, J., Zunino, P., Antúnez, K. (2015) Prevalence and distribution of honey bee pathogens in Uruguay. J. Apic. Res, in press

Antúnez, K., D'Alessandro, B., Piccini, C., Corbella, E., Zunino, P. (2004) Paenibacillus larvae larvae spores in honey samples from Uruguay: a nationwide survey. J. Invertebr. Pathol. 86, 56-58

Antúnez, K., D’Alessandro, B., Corbella, E., Ramallo, G., Zunino, P. (2006) Honeybee viruses in Uruguay. J. Invertebr. Pathol. 93, 67-70

Antúnez, K., Piccini, K., Castro-Sowinski, S., Rosado, C., Seldin, L., Zunino, P. (2007) Phenotypic and genotypic characterization of Paenibacillus larvae isolates. Vet. Microbiol 124 (1-2), 178-183

Antúnez, K., Harriet, J., Gende, L., Maggi, M., Eguaras, M., Zunino, P. (2008) Efficacy of natural propolis extract in the control of American Foulbrood. Vet. Microbiol. 131, 324-331

Antúnez, K., Anido, M., Branchiccela, B., Harriet, J., Campa, J., Zunino, P. (2012) American Foulbrood in Uruguay: twelve years from its first report. J. Invertebr. Pathol. 110, 129-131

Antúnez, K., Anido, M., Branchiccela, B., Harriet, J., Campa, J., Invernizzi, C., et al. (2015) Seasonal variation of honeybee pathogens and its association with pollen diversity in Uruguay. Microb. Ecol. 70, 522-533

Arbulo, N., Antúnez, K., Salvarrey, S., Santos, E., Branchiccela, B., Martín-Hernández, R., Higes, M., Invernizzi, C. (2015) High prevalence and infection levels of Nosema ceranae in bumblebees Bombus atratus and Bombus bellicosus from Uruguay. J. Invertebr. Pathol. 130, 165-168

Audisio, C., Torres, M.J., Sabate, D.C., Ibarguren, C., Apella, M.C. (2011) Properties of different lactic acid bacteria isolated from Apis mellifera L. bee-gut. Microbiol. Res. 166, 1-13

Barbosa, W.F., Smagghe, G., Guedes, R.N.C. (2015) Pesticides and reduced-risk insecticides, native bees and pantropical stingless bees: Pitfalls and perspectives. Pest Manag. Sci. 71 (8), 1049-1053

Barriga, G.P., Cifuentes-Munoz, N., Rivera, P.A., Gutierrez, M., Shmaryahu, A., Valenzuela, P.D., Engel, E.A. (2012) First detection and complete genome sequence of Deformed wing virus in Chilean honeybees. Virus Genes 45, 606-609

Bastos, E.M., Simone, M., Jorge, D.M., Soares, A.E., Spivak, M. (2008) In vitro study of the antimicrobial 
activity of Brazilian propolis against Paenibacillus larvae. J. Invertebr. Pathol. 97, 273-281

Branchiccela, B., Aguirre, C., Parra, G., Estay, P., Zunino, P., Antúnez, K. (2014) Genetic changes in Apis mellifera after forty years of Africanization. Apidologie 45 (6), 752-756

Brasesco, C., Silvina, S., Negri, P., Medici, S., Ruffinengo, S., Eguaras, M., Maggi, M. (2013) Detección mediante PCR en tiempo Real de tres virus patógenos de Apis mellifera en el sudeste de la provincia de Buenos Aires. VIII Encuentro Biólogos en Red. Mar del Plata, Argentina

Bravo, J., Carbonell, V., Valdebenito, J.T., Figueroa, C., Valdovinos, C.E., Martín-Hernández, R., Higes, M., Delporte, C. (2014) Identification of Nosema ceranae in the Valparaíso District, Chile. Arch. Med. Vet. 46, 487-491

Buchmann, S., Nabhan, G. (1996) The Forgotten Pollinators. Island Press, Washington, 1032 DC

Carneiro, F.E., Torres, R.R., Strapazzon, R., Ramírez, S.A., Guerra Jr., J.C., Koling, D.F., Moretto, G. (2007) Changes in the reproductive ability of the mite Varroa destructor (Anderson e Trueman) in Africanized honey bees (Apis mellifera L.) (Hymenoptera: Apidae) colonies in southern Brazil. Neotrop. Entomol. 36(6), 949-952

Carvalho, A.C.P., Message, D. (2004) A scientific note on the toxic pollen of Stryphnodendron polyphyllum (Fabaceae, Mimosoideae) which causes sacbrood-like symptoms. Apidologie 35, 89-90

Casanova, O. (2000) Evolución del comportamiento grooming contra Varroa jacobsoni (Acari: Dermanicidae) en abejas africanizadas (Hymenoptera: Apidae) en el estado Táchira, Venezuela. Revista Cientifica UNET, Organo Divulgatorio del Decanato de Investigación de la Universidad Experimental del Táchira, San Cristobal Venezuela. Rev. Cient. UNET 12 (1), 1-10

Casanova, O., Perruolo, G. (1992) Parasitic diseases of the honey bee Apis mellifera in Tachir, Venezuela. Vida Apícola 54, 20-24. ISSN 0213-1015

Castilla, R., Reynaldi F., Sguazza G., Pecoraro M., Galosi C. (2015) Determinación de virus que afectan a las abejas durante el período 2009-2014. XXXV Reunión Científica Anual Sociedad Argentina de Virología.

Castro, A., Medici, S., Sarlo, E., Eguaras, E. (2010) Agregado de parafina en ceras estampadas y su efecto sobre el labrado de panales y viabilidad de las crías de Apis mellifera. Zootec. Trop. 28(3), 353-361

Cintra, P., Malaspina, O., Bueno, O.C. (2003) Toxicity of barbatimao to Apis mellifera and Scaptotrigona postica, under laboratory conditions. J. Apic. Res. 42, 9-12

Collet, T., Ferreira, K.M., Arias, M.C., Soares, A.E., Del Lama, M.A. (2006) Genetic structure of Africanized honeybee populations (Apis mellifera L.) from Brazil and Uruguay viewed through mitochondrial DNA COI-COII patterns. Heredity 97, 329-335
Cornejo, L., Rossi, C.O., Davila, M. (1970) Studies on the effect of Nosema apis on honey production. $1 \mathrm{deg}$ Congresso Brasileiro de Apicultura 189-195

Corrêa-Marques, M.H., Issa, M.R.C., De Jong, D.D. (2000) Classification and quantification of damaged Varroa jacobsoni found in the debris of honey bee colonies as criteria for selection? Am. Bee J. 140 (10), 820-824

Cox-Foster, D.L., Conlan, S., Holmes, E.C., Palacios, G., Evans, J.D., Moran, N.A., Martinson, V. (2007) A metagenomic survey of microbes in honey bee colony collapse disorder. Science 318 (5848), 283-287

Currie, R.W., Pernal, S.F., Guzmán-Novoa, E. (2010) Honey bee colony losses in Canada. J. Apic. Res. 49(1), 104-106

Damiani, N., Maggi, M., Gende, L., Faverin, C., Eguaras, M., Marcangeli, J. (2010) Evaluation of the toxicity of a propolis extract on Varroa destructor (Acari: Varroidae) and Apis mellifera (Hymenoptera: Apidae). J. Apic. Res. Bee World 49 (3), 257-264

Damiani, N., Fernández, N.J., Porrini, M.P., Gende, L.B., Alvarez, E., Buffa, F., et al. (2014) Laurel leaf extracts for honeybee pest and disease management: antimicrobial, microsporicidal, and acaricidal activity. Parasitol. Res. 113, 701-709

De Jong, D. (1984) Africanized bees now preferred by Brazilian beekeepers. Am. Bee J. 124, 116-118

De Jong, D., Soares, A.E.E. (1997) An isolated population of Italian bees that has survived Varroa jacobsoni infestation without treatment for over 12 years. Am. Bee J. 137, 742-745

De Jong, D., Morse, R.A., Eickwort, G.C. (1982) Mite pests of honey bees. Annu. Rev. Entomol. 27, 229-252

Delaplane, K. (2014) Africanized honeybees. Http:// extension.uga.edu/publications/files/pdf/ B\%201290_3.PDF (accesed on 27 december 2015)

DIGEGRA-MGAP (2014) Registro nacional de propietarios de colmenas (RNPC) 2014.http:// www.mgap.gub.uy (accesed on 2 march 2016)

Eguaras, M., Ruffinengo, S. (2006) Estrategias para el control de Varroa. Editorial Martin. Mar del Plata, Argentina

Eguaras, M., Marcangeli, J., Oppedisano, M., Sardella, N. (1998) Prevalencia e Intensidad del ácaro de las tráqueas en colmenas de Argentina. Apiacta XXXIII , 46-48

Ellis, J.D., Evans, J.D., Pettis, J. (2010) Colony losses, managed colony population decline, and Colony Collapse Disorder in the United States. J. Apic. Res. 49 (1), 134-136

Fernández, N., García, O. (1997) Disminución de la eficacia del fluvalinato en el control del acaro Varroa jacobsoni en Argentina. La Gaceta del Colmenar 4, 14-18

Flechtmann, C.H.W. (1977) A abelha "Africanizada" e a dissemina cao do Acarapis woodi (Rennie) no Brazil. Anais da Sociedade Entomologica do Brazil 6(1), 130-131

Freiberg, M., De Jong, D., Message, D., Cox-Foster, D. (2012) First report of sacbrood virus in honey bee (Apis 
mellifera ) colonies in Brazil. Genet. Mol. Res. 11, 3310-3314

Fuselli, S., García de la Rosa, S.B., Eguaras, M., Fritz, R. (2010) In vitro antibacterial effect of exotic plants essential oils on the honeybee pathogen Paenibacillus larvae, causal agent of American foulbrood. Span. J. Agric. Res. 8, 651-657

Gamboa, V., Ravoet, J., Brunain, M., Smagghe, G., Meeus, I., Figueroa, J., de Graaf, D.C. (2015) Bee pathogens found in Bombus atratus from Colombia: A case study. J. Invertebr. Pathol. 2, 317-320

Giacobino, A., Bulacio Cagnolo, N., Merke, J., Orellano, E., Bertozzi, E., Masciangelo, G., Pietronave, H., Salto, C., Signorini, M. (2014) Risk factors associated with the presence of Varroa destructor in honey bee colonies from east-central Argentina. Prev. Vet. Med. 115 (3-4), 280-287

González, M.J., Beoletto, V.G., Agnese, A.M., Audisio, M.C., Marioli, J.M. (2015) Purification of substances from Achyrocline satureioides with inhibitory activity against Paenibacillus larvae, the causal agent of American foulbrood in honeybees' larvae. Appl. Biochem. Biotechnol. 175, 3349-3359

Harriet, J., Campa, J., Mendoza, Y. (2013) Loque Americana: Cartilla $\mathrm{N}^{\circ} 22$. [online] http:/www.ainfo.inia.uy/ digital/bitstream/item/3821/1/Cartilla-22.pdf (accessed on 27 July 15)

Herbert, L., Vázquez, D., Arenas, A., Farina, W. (2014) Effects of field-realistic doses of glyphosate on honeybee appetitive behaviour. J. Exp. Biol. 217, 34573464

Hinojosa, A., González, D. (2004) Prevalencia de parásitos en Apis mellifera en colmenares del secano costero e interior de la VI Región, Chile. Parasitol. Latinoam. 59, 137-141

FAOSTAT (2016) http://faostat3.fao.org/browse/Q/QC/S (accesed on 2 march 2016)

Huaiquil, S.E., Sepúlveda, G.F., Rebolledo, R. (2009) Sanidad apícola en el valle de Azapa

Invernizzi, C., Abud, C., Tomasco, I.H., Harriet, J., Ramallo, G., et al. (2009) Presence of Nosema ceranae in honeybees (Apis mellifera) in Uruguay. J. Invertebr. Pathol. 101 , 150-153

Invernizzi, C., Antúnez, K., Campa, J.P., Harriet, J., Mendoza, Y., Santos, E., Zunino, P. (2011) Situación sanitaria de las abejas melíferas en Uruguay. Veterinaria 47, 15-27

Invernizzi, C., Zefferino, I., Santos, E., Sánchez, L., Mendoza, Y. (2016) Multilevel assessment of grooming behavior against Varroa destructor in Italian and Africanized honey bees. J. Apic. Res, in press

Jacob, C.R., Soares, H.M., Nocelli, R.C., Malaspina, O. (2015) Impact of fipronil on the mushroom bodies of the stingless bee Scaptotrigona postica. Pest Manag. Sci. 71 (1), 114-122

Junkes, L., Guerra Júnior, J.C.V., Moretto, G. (2007) Varroa destructor mite mortality rate according to the amount of worker broods in Africanized honey bee (Apis mellifera L.) colonies. Acta Sci. Biol. Sci. 29, 305-308

Klee, J., Besana, A.M., Genersch, E., Gisder, S., Nanetti, A., Tam, D.Q., Message, D. (2007) Widespread dispersal of the microsporidian Nosema ceranae, an emergent pathogen of the western honey bee, Apis mellifera. J. Invertebr. Pathol. 96(1), 1-10

Klein, A.M., Brittain, C., Hendrix, S.D., Thorp, R., Williams, N., Kremen, C. (2012) Wild pollination services to California almond rely on semi-natural habitat. J. Appl. Ecol. 49 (3), 723-732

Kremen, C., Williams, N.M., Thorp, R.W. (2002) Crop pollination from native bees at risk from agricultural intensification. Proc. Natl. Acad. Sci. 99 (26), 1681216816

Lanzi, G., de Miranda, J.R., Boniotti, M.B., Cameron, C.E., Lavazza, A., et al. (2006) Molecular and biological characterization of deformed wing virus of honeybees (Apis mellifera L.). J. Virol. 80, 4998-5009

Laval, E., Eguillor, P., Barrera, D. (2010) Sector apícola chileno: localización del sector y cambios intercensales (1997-2007) bajo una perspectiva de género. Oficina de Estudios y Políticas Agrarias (ODEPA), Santiago, Chile. Available at http://www.odepa.gob.cl/ odepaweb/publicaciones/doc/2290.pdf (accessed 27 December 2015)

Le Conte, Y., Ellis, M., Ritter, W. (2010) Varroa mites and honey bee health: can Varroa explain part of the colony losses? Apidologie 41 (3), 353-363

Lee, K., Steinhauer, N., Rennich, K., Wilson, M., Tarpy, D., et al. (2015) A national survey of managed honey bee 2013-2014 annual colony losses in the USA. Apidologie 46 (3), 292-305

Lourenço, C.T., Carvalho, S.M., Malaspina, O., Nocelli, R.C.F. (2012) Determination of fipronil LD 50 for the brazilian bee Melipona scutellaris . Julius-Kühn-Archiv 437 (1), 174-178. doi:10.5073/jka.2012.437.046

Lozano, L.G., Moffett, J.O., Campos, B., Wilson, W.T. (1987) Tracheal mite, Acarapis woodi, infestations in honey bees in Tamaulipas, Mexico. Am. Bee J. 127 (12), 847

Lucia, M., Reynaldi, F.J., Sguazza, G.H., Abrahamovich, A.H. (2014) First detection of deformed wing virus in Xylocopa augusti larvae (Hymenoptera: Apidae) in Argentina. J. Apic. Res. 53 (4), 466-468

Maggi, M., Ruffinengo, S., Damiani, N., Sardella, N., Eguaras, M. (2009) A First detection of Varroa destructor resistance to coumaphos in Argentina. Exp. Appl. Acarol. 47(4), 317-320

Maggi, M., Ruffinengo, S., Gende, L., Eguaras, M., Sardella, N. (2008) Baseline LC $_{50}$ levels of Amitraz, Coumaphos, Fluvalinate and Flumethrine in populations of Varroa destructor from Buenos Aires Province, Argentina. J. Apic. Res. 47 (4), 292-295

Maggi, M., Ruffinengo, S., Negri, P., Eguaras, M. (2010) Resistance phenomena to amitraz from populations of the ectoparasitic mite Varro destructor of Argentina. Parasitol. Res. 107 (5), 1189-1192 
Maggi, M.D., Ruffinengo, S.R., Mendoza, Y., Ojeda, P., Ramallo, G., Floris, I., Eguaras, M.J. (2011) Susceptibility of Varroa destructor (Acari: Varroidae) to synthetic acaricides in Uruguay: Varroa mites' potential to develop acaricide resistance. Parasitol. Res. 108, 815-821

Maggi, M., Medici, S., Quintana, S., Ruffinengo, S., Marcángeli, J., Gimenez, M.P., Fuselli, S., Eguaras, M. (2012) Genetic structure of Varroa destructor populations infesting Apis mellifera colonies in Argentina. Exp. Appl. Acarol. . doi:10.1007/s10493-012-9526-0

Maggi, M., Ruffinengo, S., Negri, P., Brasesco, C., Medici, S., et al. (2013) The status of bee health and colony losses in Argentina. In: Honeybees: Foraging Behavior, Reproductive Biology and Diseases. Ed. Cameron Molley. Nova Publishing Group. ISBN: 978-1-62948661-1. p. 212-234

Maggi, M., Tourn, E., Negri, P., Szawarski, N., Marconi, A., et al. (2015) A new formulation of oxalic acid for Varroa destructor control applied in Apis mellifera colonies in the presence of brood. Apidologie . doi:10.1007/s13592-015-0405-7

Maharramov, J., Meeus, I., Maebe, K., Arbetman, M., Morales, C., et al. (2013) Genetic Variability of the Neogregarine Apicystis bombi, an Etiological Agent of an Emergent Bumblebee Disease. PLoS ONE 8(12), e81475

Malaspina, O., de Souza, T.F., Zacarin, E.C.M.S., Cruz, A.S., de Jesus, D. (2008) Efeitos Provocados por Agrotóxicos em Abelhas no Brasil. Anais do VIII Encontro Sobre Abelhas. (De Jong D. et al. editors). Ribeirao Preto, pp. 41-48. FUNPEC Editora, Ribeirao Preto

Marcangeli, J., Monetti, L., Fernandez, N. (1992) Malformations produced by Varroa jacobsoni on Apis mellifera in the province of Buenos Aires, Argentina. Apidologie 23, 399-402

Marcangeli, J., García, M., Distéfano, L. (2005) Programa sanitario apícola del partido de Mar Chiquita. Relevamiento de las enfermedades de abejas. XVII Congreso Latinoamericano de Parasitología. Mar del Plata, Argentina

Martínez, J., Leal, G., Conget, P. (2012) Nosema ceranae an emergent pathogen of Apis mellifera in Chile. Parasitol. Res. 111, 60-607

Medici, S., Castro, A., Sarlo, G., Marioli, J., Eguaras, M. (2011) The concentration effect of selected acaricides present in beeswax foundation on the survival of Apis mellifera colonies. J. Apic. Res. 2, 164-168

Medici, S.K., Sarlo, E.G., Porrini, M.P., Braunstein, M., Eguaras, M.J. (2012) Genetic variation and widespread dispersal of Nosema ceranae in Apis mellifera apiaries from Argentina. Parasitol. Res. 110, 859-864

Medici, S., Maggi, M., Sarlo, E., Ruffinengo, S., Marioli, J., Eguaras, M. (2015) Presence of syntethic acaricides in beeswax and its relationship with the development of resistance in Varroa destructor. J. Apic. Res. 53, In Press

Mendoza, Y., Díaz-Cetti, S., Ramallo, G., Invernizzi, C. (2012a) Incidencia de Nosema ceranae durante el invierno en colonias de abejas melíferas retiradas de una forestación de Eucalyptus grandis . Veterinaria 48 , 13-19

Mendoza, Y., Harriet, J., Campá, J., Roth, F., Termezana, D., Mancuello, M. (2012b) Mal del Río o Mal de Santa Lucía. Actualidad Apícola 94, 8-9

Mendoza, Y., Harriet, J., Campa, J., Katz, H., Ramallo, G., Díaz-Cetti, S., Invernizzi, C. (2013) Control de Nosema ceranae en colonias de abejas (Apis mellifera) en forestaciones de Eucalyptus grandis . Agrociencia 17, 108-113

Mendoza, Y., Santos, E., Antúnez, K., Invernizzi, C. (2014) Selección bidireccional de Apis mellifera (Hymenoptera: Apidae) para aumento de la resistencia y la susceptibilidad a la nosemosis. Rev. Soc. Entomol. Argent. 73, 65-69

Message, D., Ball, B.V., Allen, M. (1996) Ocorrência de Viroses em Abelhas no Brazil e na Argentina. XI Congresso Brazileiro de Apicultura, Salvador. Brazil

Message, D., Silva, I.C., De Jong, D., Simões, Z.L.P., Teixeira, E.W. (2010) CCD (Colony Collapse Disorder) ocorre em abelhas Apis mellifera (africanizadas)? Um relato de caso. In: Anais do X Congresso Iberolatinoamericano de Apicultura, Natal, RN. CD

Message, D., Teixeira, E.W., De Jong, D. (2012) Situação da Sanidade das abelhas no Brasil. In: Polinizadores no Brasil: Contribuição e Perspectivas para a Biodiversidade. Orgs. V.L. Imperatriz-Fonseca; D.A.L. Canhos; D.A. Alves; A.M. Saraiva - São Paulo. Editora da Universidade de São Paulo, 488 p

Ministerio de Agricultura (MAG), Brazil (2008) Prog. Nacional de Sanidade Apícola-PNSAp. [online] www.agricultura.gov.br/animal/sanidade-animal/ programas/prog-nacional-sanidade-apicola-PNSAp (accessed on 27 July 15)

Montiel, E., Piola, G. (1976) A new enemy of bees. In: Harnaj, V. (ed.) Varroasis a honey bee disease, pp. 36-38. Apimondia Publishing House, Bucharest

Morais, M. (2009) Africanized honey bees are efficient at detecting, uncapping and removing dead brood. Genet. Mol. Res. 8, 718-724

Morán, A. (2011) Actual situation of American Foulbrood in Chile, according the Project Fondo SAG N ${ }^{\circ} 24$ and projections. $42^{\circ}$ Congreso Internacional Apimondia Buenos Aires, Argentina

Moretto, G. (2002) Mortality of Varroa destructor in broodless africanizel and carnica honey bee (Apis mellifera L.) colonies. Interciencia 27 (12), 702-704

Moretto, G., Gonçalves, L.S., De Jong, D., Bichuette, M.Z. (1991) The effects of climate and bee race on Varroa jacobsoni Oud. infestations in Brazil. Apidologie 22, 197-203

Negri, P., Maggi, M., Ramirez, L., De Feudis, L., Szawarski, N., Quintana, S., Eguaras, M., Lamattina, L. (2015) Abscisic acid enhances the immune response in Apis mellifera and contributes to the colony fitness. Apidologie . doi:10.1007/s13592-014-0345-7 
Neira, M., Dussaubat, C., Manquián, N., Bahamonde, P., Vera, M. (2007) Sanidad apícola en Chile, situación de las principales enfermedades. Agro Sur 35 (1), 47-48

Neumann, P., Carreck, N. (2010) Honey bee colony losses. J. Apic. Res. 49, 1-6

Nguyen, B., Saegerman, C., Pirard, C., Mignon, J., Widart, J., Thirionet, B. (2009) Does imidacloprid seed-treated maize have an impact on honey bee mortality? J. Econ. Entomol. 102, 616-623

OIE (World Organization for Animal Health) (2014) Sanitary report and diseases worldwide [online] http:// www.oie.int/wahis_2/public/wahid.php/ Countryinformation/Animalsituation (accesed on 24 July 15)

Pacheco, P. (2012) Soybean and oil palm expansion in South America: A review of main trends and implications. Working Paper 90. CIFOR, Bogor, Indonesia

Pareja, L., Colazzo, M., Perez-Parada, A., Niell, S., Carrasco-Letelier, L., et al. (2011) Detection of pesticides in active and depopulated beehives in Uruguay. Int. J. Environ. Res. Public Health 8, 3844-3858

Piana, M., Brum, T.F., Boligon, A.A., Alves, C.F., Freitas, R.B., et al. (2015) In vitro growth-inhibitory effect of Brazilian plants extracts against Paenibacillus larvae and toxicity in bees. An. Acad. Bras. Cienc. 87, 10411047

Piccini, C., Zunino, P. (2001) American foulbrood in Uruguay: Isolation of Paenibacillus larvae larvae from larvae with clinical symptoms and adult honeybees and susceptibility to oxytetracycline. J. Invertebr. Pathol. 78, 176-177

Piccirillo, G.A., Gonzalez, D.E. (1995) Distribución de los apiarios y diagnóstico sanitario de abejas africanizadas, Apis mellifera scutellata (L) (Hymenoptera: Apidae) del estado Zulia, Venezuela. Rev. Fac. Agron. (LUZ) 12, 269-283

Plischuk, S., Martín-Hernández, R., Prieto, L., Lucía, M., Botías, C., Meana, A., Higes, M. (2009) South American native bumblebees (Hymenoptera: Apidae) infected by Nosema ceranae (Microsporidia), an emerging pathogen of honeybees (Apis mellifera). Environ. Microbiol. Rep. 1 (2), 131-135

Potts, S.G., Biesmeijer, J.C., Kremen, C., Neumann, P., Schweiger, O., Kunin, W.E. (2010) Global pollinator declines: trends, impacts and drivers. Trends Ecol. Evol. 25 (6), 345-353

Principal, J., Barrios, C. (2009) Situación de la Varroosis en Venezuela. Memorias IV Convención de Apicultura. Tarabana, Lara. Venezuela

Principal, J., Samtos Moros, V., Laguna, F. (1991) Varroasis en Venezuela. In: Proceeding XII Congreso Venezolano de Entomología. Mérida, Venezuela. p 22

Principal, J., D’Aubeterre, R., Graterol, Z. (2004) Prevalence of Varroa destructor in Africanized honeybees (Apis mellifera scutellata Lepeletier) in Lara state, Venezuela. The IBRA International Conference in Tropical Bees and VI Encontro Sobre Abelhas. Riberao Preto, Brasil
Reynaldi, F.J., Sguazza, G.H., Pecoraro, M.R., Tizzano, M.A., Galosi, C.M. (2010) First report of viral infections that affect argentine honeybees. Environ. Microbiol. Rep. 2, 749-751

Reynaldi, F.J., Sguazza, G.H., Tizzano, M.A., Fuentealba, N., Galosi, C.M., Pecoraro, M.R. (2011) First report of Israeli acute paralysis virus in asymptomatic hives of Argentina. Rev. Argent. Microbiol. 43, 84-86

Reynaldi, F.J., Sguazza, G.H., Albicoro, F.J., Pecoraro, M.R., Galosi, C.M. (2013) First molecular detection of co-infection of honey bee viruses in asymptomatic Bombus atratus in South America. Braz. J. Biol. 73 (4), 797-800

Rodríguez, M., Vargas, M., Gerding, M., Navarro, H., Antúnez, K. (2012) Viral infection and Nosema ceranae in honey bees (Apis mellifera) in Chile. J. Apic. Res. 51, 285-287

Rodríguez, M., Vargas, M., Antúnez, K., Gerding, M., Castro, F., Zapata, N. (2014) Prevalence and phylogenetic analysis of honey bee viruses in the Bio-Bio Region, Chile, and their association with other honey bee pathogens. Chilean J. Agric. Res. 74, 170-177

Rosenzweig, M.L. (1975) On continental steady states of species diversity. In: Cody, M., Diamond, J. (eds.) The Ecology and Evolution of Communities, pp. 121-140. Harvard University Press, Cambridge

de Almeida Rossi, C., Roat, T.C., Tavares, D.A., CintraSocolowski, P., Malaspina, O. (2013) Effects of sublethal doses of imidacloprid in malpighian tubules of africanized Apis mellifera (Hymenoptera, Apidae). Microsc. Res. Tech. . doi:10.1002/jemt.22199

Sabate, D.C., Gonzalez, M.J., Porrini, M.P., Eguaras, M.J., Audisio, M.C., Marioli, J.M. (2012) Synergistic effect of surfactin from Bacillus subtilis $\mathrm{C} 4$ and Achyrocline satureioides extracts on the viability of Paenibacillus larvae. World J. Microbiol. Biotechnol. 28, 1415-1422

Santos, R.C., dos Santos Alves, C.F., Schneider, T., Lopes, L.Q., Aurich, C., Giongo, J.L. (2012) Antimicrobial activity of Amazonian oils against Paenibacillus species. J. Invertebr. Pathol. 109, 265-268

Santos, L., Alves, M., Message, D., Pinto, F., Silva, M., Teixeira, E. (2014) Honey Bee Health in Apiaries in the Vale do Paraíba, São Paulo State, Southeastern Brazil. Sociobiology 61 (3), 307-312

Sattler, A. (2008) Estatus da Sanidade Apícola das Abelhas Melíferas no Sul do Brasil. Mesa redonda: Estatus da sanidade apícola das abelhas melíferas brasileiras. 17 Congresso Brasileiro de Apicultura. Minas Gerais, Brasil

Schuch, D.M.T., Tochetto, L.G., Sattler, A. (2003) Isolamento de esporos de Paenibacillus larvae subsp. larvae no Brasil. Pesq. Agrop. Brasileira 38, 353-354

SENASA (Animal Health National Service Argentina) (2005) Enfermedades de las Abejas. Manual de procedimientos [online] http://www.senasa.gov.ar/ Archivos/File/File5026-manual-enf-abejas.pdf (accessed on 24 July 15)

SENASA (Animal Health National Service) (2007) Situación actual de Varroosis [online] http:// 
www.senasa.gov.ar/Archivos/File/File3824-varroosisaituacion-actual-argentina.pdf (accessed on 27 July 15)

SENASA (Animal Health National Service) (2015) [on$1 \mathrm{ine}$ ] http:// w w w. senasa.gov.ar/ contenido.php?to $=\mathrm{n} \& \mathrm{in}=1606 \& \mathrm{io}=27155$

SENASA (Animal Health National Service) Estudio epidemiológico sobre las principales enfermedades apícolas en colmenas trashumantes de la región patagonia norte (2012) [online] http://www.senasa.gov.ar/ Archivos/File/File6837-trashumantes\%202012.pdf (accessed on 27 July 15)

Servicio Agrícola Ganadero (SAG), Chile (2006) Informe final del brote de Loque Americana en Chile [online] w w w. s a g. c $1 / \mathrm{s}$ i t e s/d e fa u $1 \mathrm{t} / \mathrm{f}$ i l e s / INFORME_FINAL_BROTE_OCTUBRE_2005.PDF (accessed on 20 July 15 )

Servicio Agrícola y Ganadero (SAG), Chile (2007) Medida sanitaria para el control de enfermedades de las abejas denominada Loque Americana [online]

Servicio Agrícola y Ganadero (SAG), Chile (2010) Informe de Caso de Nosema ceranae en la Región del Biobío, octubre de 2009 [online] http://www.sag.cl/sites/default/files/informe_caso_nosema_ceranae_BioBio_2009.pdf (accessed on $\overline{9}$ February 15)

Servicio Agrícola y Ganadero (SAG), Chile (2015) Informe Sanidad Animal Chile 2014 [online]http:// w w w.sag.gob.cl/sites/default/files/ situacion sanitaria animal 2013 0.pdf (accessed on 25 July $1 \overline{5})$

Silva, I., Message, D., Cruz, C., Campos, L., Sousa-Majer, M. (2009) Rearing Africanized honey bee (Apis mellifera L.) brood under laboratory conditions. Genet. Mol. Res. 8(2), 623-629

Strapazzon, R., Carneiro, F.E., Guerra-Júnior, J.C.V., Moretto, G. (2009) Genetic characterization of the miteVarroa destructor (Acari: Varroidae) collected from honey bees Apis mellifera (Hymenoptera, Apidae) in the state of Santa Catarina, Brazil. Genet. Mol. Res. 8, 990-997

Szawarski, N., Levy, E., Maggi, M. (2013) Relevamiento de acarapisosis en colmenares de explotación comercial de Argentina. VIII Encuentro Biólogos En Red. Mar del Plata (Argentina). 14 y 15 de Noviembre de 2013

Tavares, D.A., Roat, T.C., Carvalho, S.M., Silva-Zacarin, E.C.M., Malaspina, O. (2015) In vitro effects of thiamethoxam on larvae of Africanized honey bee Apis mellifera (Hymenoptera: Apidae). Chemosphere 135, $370-378$

Teixeira, E.W., Chen, Y., Message, D., Pettis, J., Evans, J.D. (2008) Virus infections in Brazilian honey bees. J. Invertebr. Pathol. 99, 117-119
Teixeira, E.W., Chen, Y., Message, D., Boncristiani, H., Pettis, J., Evans, J. (2012) Israeli acute paralysis virus in Africanized honey bees in southeastern Brazilian apiaries. J. Apic. Res. 51, 282-284

Teixeira, E.W., dos Santos, L.G., Sattler, A., Message, D., Alves, M.L.T.M.F. (2013) Nosema ceranae has been present in Brazil for more than three decades infecting Africanized honey bees. J. Invertebr. Pathol. 114, 250-254

Thimann, R. (2001) 25 years of the africanized honey bee in Venezuela. Proc. 37 Th Int. Apic. Congr., 28 Oct - 1 Nov 2001, Durban, South Africa. ISBN: 0-62027768-8

USAID-Brasil (2006) Análise da indústria de mel inserção de micro e pequenas empresas no mercado internacional. Vol.2. Programa de fomento às exportações de micro e pequenas empresas da USAID/Brasil. 65p. Disponível em: http:// pdf.usaid.gov/pdf_docs/Pnadm251.pdf. Access 18 de august de 2015

van der Zee, R. (2010) Colony losses in the Netherlands. J. Apic. Res. 49 (1), 121-123

Vandame, R., Palacio, M.A. (2010) Preserved honey bee health in Latin America: a fragile equilibrium due to low-intensity agriculture and beekeeping? Apidologie 41 (3), 243-255

vanEngelsdorp, D., Hayes Jr., J., Underwood, R.M., Pettis, J.S. (2008) A survey of honey bee colony losses in the U.S., fall 2007 to spring 2008. PLoS ONE 3 (12), e4071. doi:10. 1371/journal.pone.0004071

vanEngelsdorp, D., Hayes Jr., J., Underwood, R.M., Pettis, J.S. (2010) A survey of honey bee colony losses in the United States, fall 2008 to spring 2009. J. Apic. Res. 49 (1), 7-14

Vilela, D., Araújo, P.M.M. (Org.) (2006) Contribuições das Câmaras Setoriais e Temáticas à Formulação de Políticas Públicas e Privadas para o Agronegócio. Brasília: Ministério da Agricultura, Pecuária e Abastecimento - MAPA. 496 p. Disponível em http://www.agricultura.gov.br/arq_editor/ LIVRO_COMPLETO.pdf . Acesso em 18 de agosto de 2015

Wilson, W.T., Rhodes, H.A., Numaker, R.A., Stoner, A. (1985) The possible consequences of finding Acarapis woodi adults in honey bees from Venezuela, South America. Am. Bee J. 125 (9), 640-641

Xavier, M., Message, D., Picanc, M.C., Chediak, M., Ju, P.A.S., Ramos, R.S. (2015) Acute Toxicity and Sublethal Effects of Botanical Insecticides to Honey Bees. J. Insect. Sci. 15, 1-6. doi:10.1093/jisesa/iev110

Yañez, O., Tejada, G., Neumann, P. (2014) First detection of viruses in africanized honey bees from Peru. Virol. Sin. 5, 321-323 